Article

\title{
Endemic Hemicryptophyte Grasslands of the High Mountains of the Caribbean
}

\author{
Ana Cano-Ortiz ${ }^{1}$, Ricardo Quinto Canas ${ }^{2,3}$, José Carlos Piñar Fuentes ${ }^{1}$, Sara del Río ${ }^{4}$, Carlos José Pinto Gomes ${ }^{5}$ \\ and Eusebio Cano ${ }^{1, *}$
}

How to cite this paper: Cano Ortiz, A., Quinto Canas, R., Pinar Fuentes, J. C., del Rio, S., Pinto Gomes, C. J., \& Cano, E. (2022). Endemic Hemicryptophyte Grasslands of the High Mountains of the Caribbean. Research Journal of Ecology and Environmental Sciences, 2(1), 1-20. Retrieved from https://www.scipublications.com/journal/index.php/rjees/article/view/184
Received: November 20, 2021 Accepted: January 28, 2022 Published: February 9, 2022

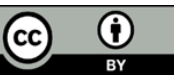

Copyright: (C) 2022 by the authors Submitted for possible open access publication under the terms and conditions of the Creative Commons Attribution (CC BY) license (http://creativecommons.org/licenses /by/4.0/).

\footnotetext{
${ }^{1}$ Department of Animal and Plant Biology and Ecology, Section of Botany, University of Jaén, Jaén, Spain

${ }^{2}$ Faculty of Sciences and Technology, University of Algarve, Campus de Gambelas, 8005-139 Faro, Portugal

${ }^{3}$ Centre of Marine Sciences (CCMAR), University of Algarve, Campus de Gambelas, 8005-139 Faro, Portugal

${ }^{4}$ Department of Biodiversity and Environmental Management (Botany), Mountain Livestock Institute (CSICULE), Faculty of Biological and Environmental Sciences, University of León, Campus de Vegazana s/n, 24071 León, Spain; sriog@unileon.es (S.D.R.)

${ }^{5}$ Department of Landscape, Environment and Planning, School of Science and Technology, MED - Mediterranean Institute for Agriculture, Environment and Development, University of Évora, 7000-671 Évora, Portugal
}

*Correspondence: ecano@ujaen.es

\begin{abstract}
Although there are numerous studies on the floristic composition of the Andean and Caribbean grasslands, there are limited information from a phytosociological point of view. This work therefore aims to highlight the differences in this important vegetation type in these two biodiversity hotspots to gain a better understanding of their floristic and vegetational richness. The floristic composition of Andean-grasslands (Ecuador) and the island of Hispaniola is also studied. The reason for this comparative analysis of Andean and Caribbean territories is their tropical character and their bioclimatic similarities. The comparative analysis of Peruvian Andean and Colombian grasslands is based on floristic knowledge from the literature, our inventories on the island of Hispaniola, and the works of Peguero. We applied the phytosociological methodology of Braun-Blanquet and the code of phytosociological nomenclature. We performed a statistical analysis to verify the differences between both community types using the statistical packages PAST@ and CAP3. The comparative analysis of Andean and Caribbean grasslands shows a clear floristic and biogeographical differentiation and reveals that the only ecological character they share is their high-mountain attribute. In the Caribbean these communities are found only on the island of Hispaniola (Dominican Republic) in the Central biogeographic sector, Central subprovince, Hispaniola province. These grasslands are exclusive to Hispaniola and have a high rate of endemics. We propose the following new syntaxa: the association Hyperico constanzae-Danthonietum domingensis, the alliance Hieracio domingensis-Deschampsion domingensis, the order Danthonietalia domingensis, and the class Deschampsio-Danthonietea domingensis. We found high biodiversity values for Andean and Caribbean areas. This is due to the intense anthropic activity on the island of Hispaniola, which has led to a high percentage of naturalized plants.
\end{abstract}

Keywords: America; association; conservation diversity; endemics; grasslands; phytosociology; vegetation.

\section{Introduction}

The high mountains host an endemic flora and a characteristic vegetation around the world [1-5], are really hotspots of biodiversity [6-8], and are present not only in continental lands, but in several islands too and many of them are studied from a botanical point of view $[9,10]$. 
The Antillean archipelago is formed by the islands in the Greater and Lesser Antilles, and is located between the Caribbean Sea and the Atlantic Ocean on an arc between Florida and Venezuela. The islands have a territorial extension of $299,000 \mathrm{~km}^{2}$, and their geological origins date from more or less 100 million years ago with the separation between Africa and America. According to some authors [11], throughout the geological eras the current islands have been shaped by three tectonic movements in the form of uplifts, subsidence and separation along faults, all of which are due to interactions between the Caribbean and the surrounding plates: Cocos, Nazca, North America and South America. The subduction of the Caribbean tectonic plate, which configured the mountains of Central America, began 25 million years ago in the Miocene era. Cuba was formed from the Mesozoic onward, specifically in the Jurassic and Cretaceous periods. The definitive separation of the Antilles from Central America occurred in the Pliocene era, leading to the establishment of essentially two migratory routes: North American route through FloridaCuba, and the route of the Lesser Antilles from Venezuela; a third route from the Yucatán peninsula through the Caiman Islands was less important due to the distance from Central America to the Antillean arc [11].

The high mountains in Cuba that developed over millions of years were the Sierra Maestra, Sierra Escambray (Guamuhaya), Sierra Turquino at $1974 \mathrm{~m}$ asl, and Pico Cuba at $1972 \mathrm{~m}$ asl. The highest altitudes in Hispaniola are the Cordillera Central with Pico Duarte (3175 m asl), Pico del Yaque (3125 m asl) and la Rosilla (2860 m asl); the Cordillera Septentrional with Pico Diego de Ocampo (1229 m asl); other mountain ranges such as Bahoruco, Hotte and La Selle and Cordillera Oriental; and finally, in Puerto Rico the Cordillera Central with altitudes of less than $1500 \mathrm{~m}$ asl [12].

The Cordillera Central has a siliceous character and dates from the Cretaceous period; it represents the highest point in the whole Caribbean. The climate in all the Antilles is tropical with frequent and abundant rains on the oceanic face-sometimes exceeding 3,000 $\mathrm{mm}$ - and low rainfall on the Caribbean face, with up to $200 \mathrm{~mm}$. The mean temperature is $24^{\circ} \mathrm{C}$, and all the islands are subjected to hurricane winds with speeds of over $200 \mathrm{~km} / \mathrm{h}$ [12].

The Antilles have undergone subsidence and uplifts throughout their geological history, although Cuba and Hispaniola have remained emerged while the rest of the islands sank into the sea; for this reason, these two islands became a reservoir for flora and subsequently served as dispersion centres [13].

The diversity of substrates, with a high frequency of siliceous, carbonated, ultramafic and serpentine rocks, its climate, and particularly its high-altitude orogeny, have given rise to a distinctive flora; these islands act as centres of speciation (hotspots) and have a very high rate of endemic plants: Cuba 45\%; Hispaniola 36\%; Jamaica 25-30\%; Puerto Rico 24\% and Lesser Antilles 10\% [14].

Grasslands are hemicryptophyte communities located in the supratropical thermotype of Central America [15]. From the bioclimatic point of view, the thermotype in the Antilles ranges between the infra- and supratropical (the latter only in Hispaniola [16], where the temperature of the supratropical thermotype drops to $0{ }^{\circ} \mathrm{C}$ in winter. The dominant thermotypes are the infra-, thermo- and mesotropical, and the ombrotype ranges between the semiarid and the hyperhumid. The supratropical belt extends to altitudes above the sea of clouds, which causes winter temperatures to drop to $0{ }^{\circ} \mathrm{C}$. These zones are characterised by their pluviseasonality, while the infra-, thermo- and mesotropical ombrotypes have a pluvial character. The inclusion of grassland communities in different phytosociological classes in the Andean region is due to the divergent floristic composition of the plant communities, their ecology and the biogeographic unit in which they are located [17].

Several authors have included Andean grasslands in various phytosociological classes. Izco [16] mentioned grasslands in a study on the San Francisco Reserve (Ecuador). 
Grassland communities may be constituted solely by hemicryptophytes or by hemicryptophytes and small shrubs. Cabrera et al. [17] ascribed the High-Andean grasslands of Peru, Bolivia, northern Argentina and Chile to Calamagrostietea vicunarum Rivas-Martínez \& Tovar 1982, and mesophilous scrublands and grasslands in temperate environments to other phytosociological classes. Galán \& Orellana [18] assigned: a) the central Peruvian grasslands on limestone materials to the class Stipetea mucronatae Gutte 1986; b) the grasslands with small shrubs and cushion heaths in dry areas and on volcanic substrates in the Andean range in Bolivia, Chile and Argentina to the class Fabiano bryoidis-Stipetea frigidae Rivas-Martínez \& Navarro in Navarro \& Maldonado 2002; and c) the grasslands on the puna and intermediate valleys in Peru and Bolivia to the class Calamagrostietea vicunarum. Grassland communities belong to different phytosociological classes because of the diversity of the Poaceae family [19-27].

None of the classes cited can be extrapolated to the Caribbean as there are significant floristic, ecological and biogeographical differences; these grassland communities in Hispaniola are located on siliceous substrates in the Cordillera Central.

Grassland communities in the Andes have been studied from a floristic standpoint by several authors $[18,19,23-27]$. Grasslands in the Antillean archipelago are located only on the island of Hispaniola, specifically in the Cordillera Central, which has been the subject of various floristic and vegetation studies as indicated above.

On the northern or windward face there is a predominance of broadleaved or rainforest of Magnolia L., Prestoea Hook, Ocotea Aubl., Podocarpus Labill., Cyathea J.E. Smith (Ocoteo-Cyrilletea racemiflorae Borhidi 1996) [28], while on the Caribbean or leeward face there are pine forests growing on serpentines at low altitudes above the sea of clouds [4, 17,29-30]. Several authors have studied the flora and vegetation of the island of Hispaniola [31-47], essentially from a floristic approach, and addressed aspects of vegetation from the physiognomic point of view. We are the only authors until now to have conducted phytosociological studies [48-51].

The island of Hispaniola is a hotspot due to the high rate of endemisms, account for 2050 out of a total of 6000 species, even compared to other well-known hot spots in the worldwide as [52-55]. This is due to its orography and diversity of climate and substrates; its ombrotype ranges from semi-arid to hyper-humid, its thermotype from infratropical to supratropical, and its substrates are siliceous, carbonate rocks and serpentines

In this work we studied the flora and vegetation of the high mountains of the Caribbean, and compare them with similar Andean plant communities to highlight the differences between these two important biodiversity hotspots in order to gain a better understanding of their floristic richness. The floristic composition of the Andean scrub (Ecuador) and the scrub on the island of Hispaniola are also studied.

\section{Materials and Methods}

\subsection{Comparative analysis}

A comparative analysis is made between the Peruvian Andean and Colombian grasslands based on the floristic presence studies of Izco et al. [20], our own relevés collected on the island of Hispaniola, and other works of Peguero [13] in Valle Nuevo (Dominican Republic).

For the samplings carried out by us in the Central mountain range we have followed the phytosociological criteria. The plot size was chosen by previously calculating the minimum area, namely $300 \mathrm{~m}^{2}$ [56]. In all cases the samplings were carried out in supratropical environments (Figures 1 and 2). For the abundance-dominance of the species, the work of Braun-Blanquet has been used [57]. 


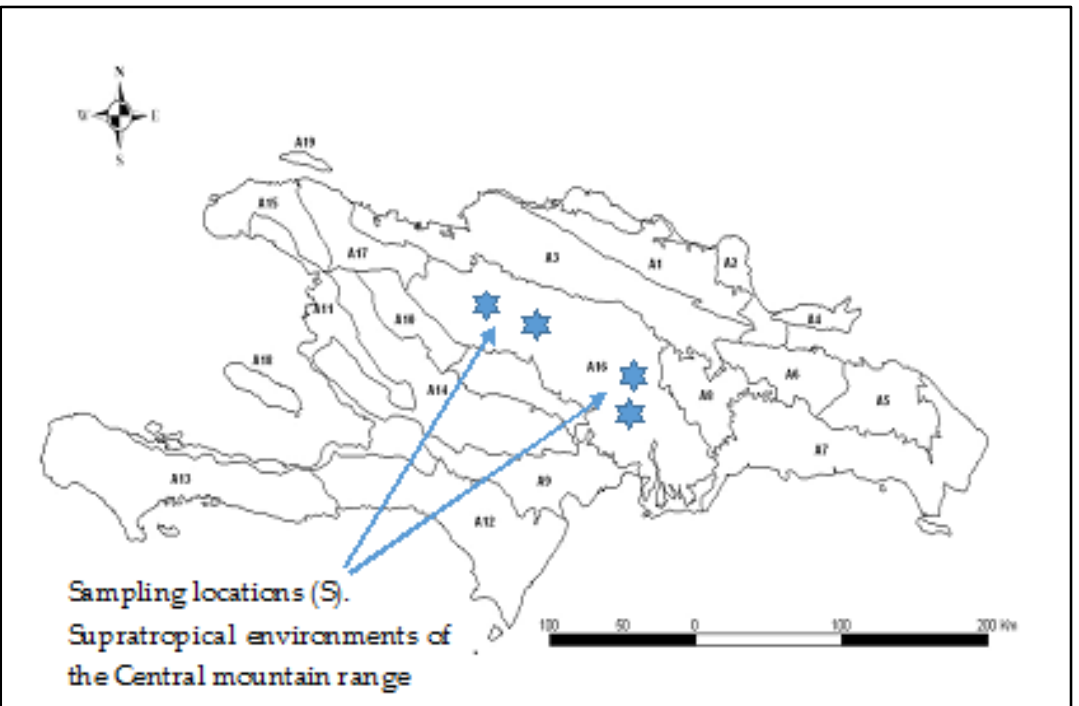

Figure 1. Localities studied. A16 Cordillera Central. Hispaniola Island.

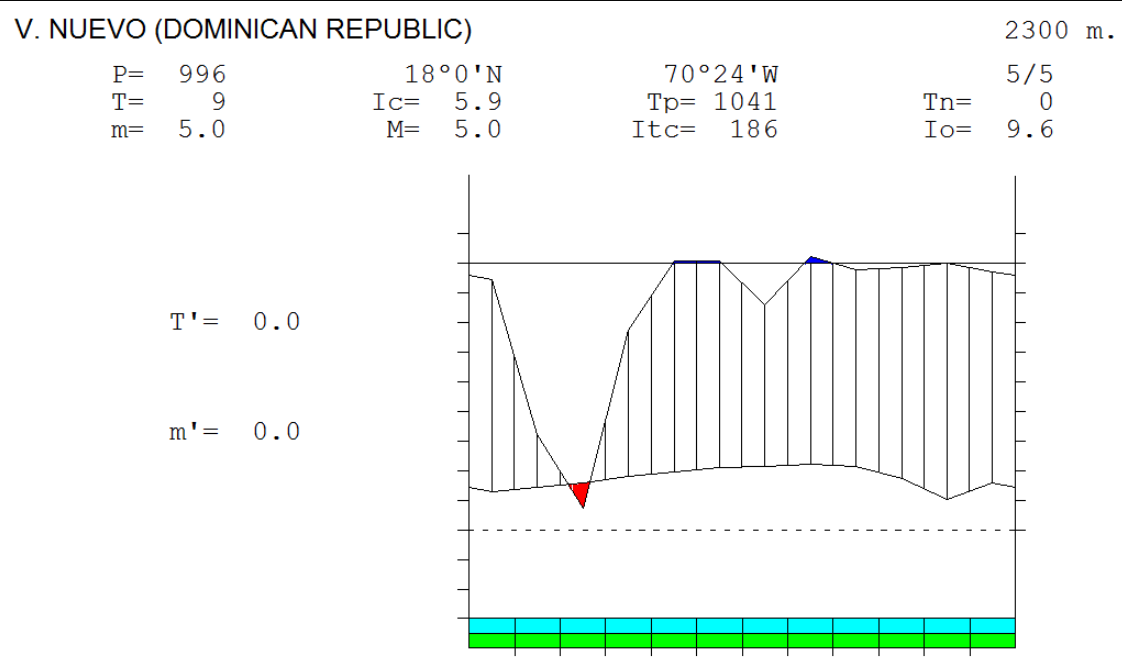

TROPICAL PLUVIAL

UPPER SUPRATROPICAL UPPER HUMID

Figure 2. Bioclimatic diagram of Valle Nuevo. Upper supratropical thermotype and upper humid ombrotype. $\mathrm{P}=$ Precipitation. $\mathrm{T}=$ Average annual temperature. $\mathrm{m}=$ Average temperature of the minimum. $\mathrm{M}=$ Average temperature of the maximums. $\mathrm{Tp}=$ Positive temperature. $\mathrm{m}=$ Average temperature of the absolute minimums. Tn = Annual negative temperature. $\mathrm{Ic}=$ Annual continentality index. Io = Annual ombrothermic index. Itc $=$ Compensated thermicity index .

\subsection{Vegetation analysis}

A study was carried out of the endemic scrub and grasslands of the Caribbean, until now exclusively located in Hispaniola.

We applied the phytosociological methodology of Braun-Blanquet [57] and the code of phytosociological nomenclature to name and describe the syntaxa [58]. A similarity analysis is carried out between areas of the Caribbean and Andean areas, through analysis of presence-absence of species and cluster. The environmental conditions have been sufficiently studied in references $[14,48,51]$.

The statistical packages PAST (Paleontological Statistics)@ [59] and CAP3 (Community Analysis Package, PISCES Conservation Ltd. IRC House, The Square, Pennington, Lymington Hants., SO41 8GN United Kingdom)@ were used for this study. We applied 
the Jaccard distance to differentiate the Andean from the Caribbean communities. For the biogeographical and bioclimatic study, we followed [60-64]. The nomenclature of the taxa reported is according to Global Biodiversity Information Facility (GBIF) [65] and the Flora of Hispaniola [66].

The Shannon-Wiener, Margalef and Simpson indices were used to determine the diversity of the plots studied, since they offer the best fit with the measurement of diversity when using the table of presence and absence of species. However, it was impossible to use the Pielou Evennes index as it does not fit well when only the presence and absence of species is used.

The hemicryptophytic communities inventoried by us and by Peguero in the Valle Nuevo National Park (Dominican Republic) present a high endemic richness with 138 endemic plants. These communities are located only in supratropical environments above altitudes of 2000 metres on siliceous substrates. As these are environments exclusive to the Central Cordillera in the Dominican Republic, they represent endemic habitats with a high ecological value [67].

\section{Results and Discussion}

These endemic communities of Hispaniola cannot be located in the phytosociological classes described before for the Andean and Caribbean. The similarity, cluster and PCA analyses show clear differences between Andean and Caribbean grasslands (Figures 3 and 4) - plots P1 to P10 in the Caribbean group and plots P11 to P15 in the Andean group with a significant floristic difference between the two groups (Tables S1 and S2, Supplementary materials). Although the analysis represented in Figure 3 is not exhaustive, it shows the significant differences between both territories. According to the Simpson, Shannon and Margalef diversity indices, this diversity is greater in the Andean plots (Table 1), where the mean diversity Pm (Simpson, Shannon and Margalef) of the plots is 0.94, 2.89 and 6.37 respectively. Some Andean plots have a maximum diversity of $0.97,3.49$ and 9.15, while the maximum diversity in Hispaniola is $0.94,2.89$ and 5.88 respectively, and their mean diversity Pm is 0.91, 2.45 and 4.46. This is possibly due to intense anthropic activity in the plots on the island, which have $31.25 \%$ of endemic species, $37.5 \%$ of native species and $31.25 \%$ of naturalized plants (10 species) (Figure 5).

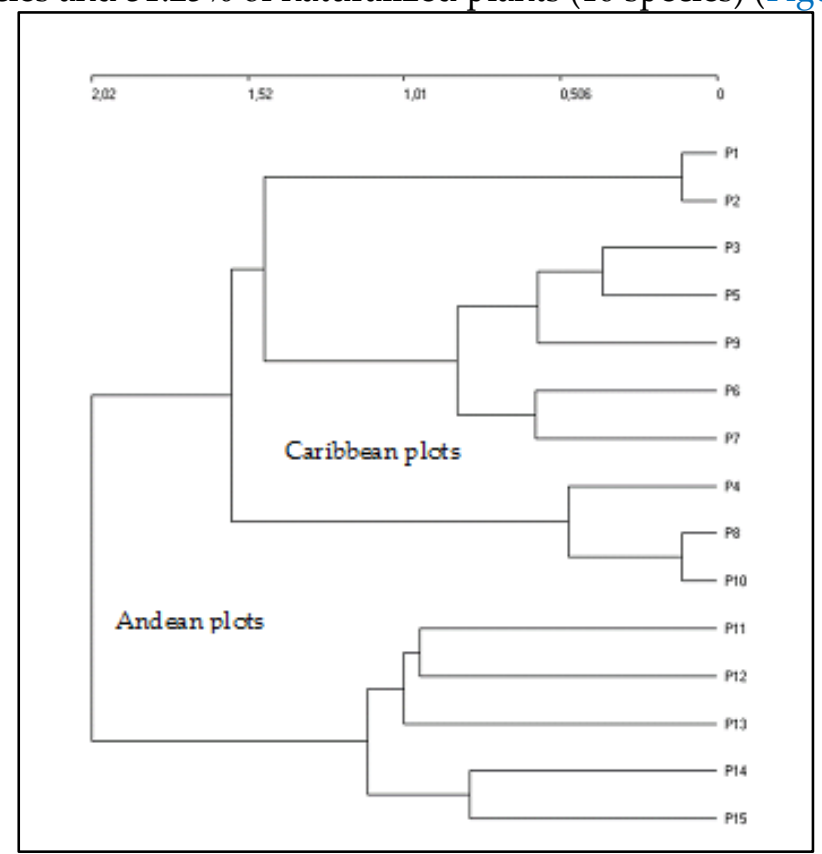

Figure 3. Comparative analysis of the Caribbean (P1-P10) and Andean (P11-P15) plots. 


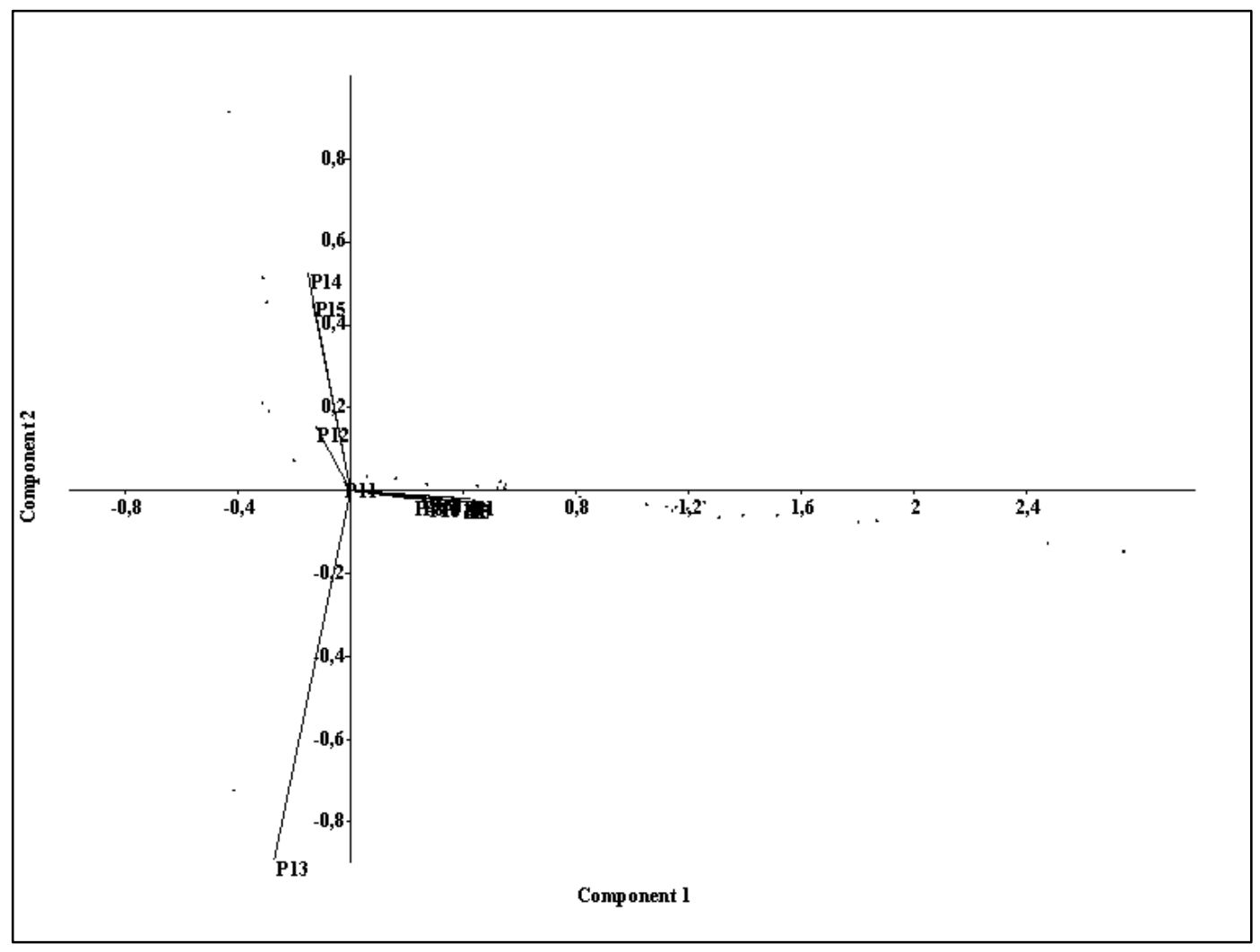

Figure 4. PCA analysis with separation of Andean and Caribbean plots. Caribbean (P1-P10) and Andean (P11-P15).

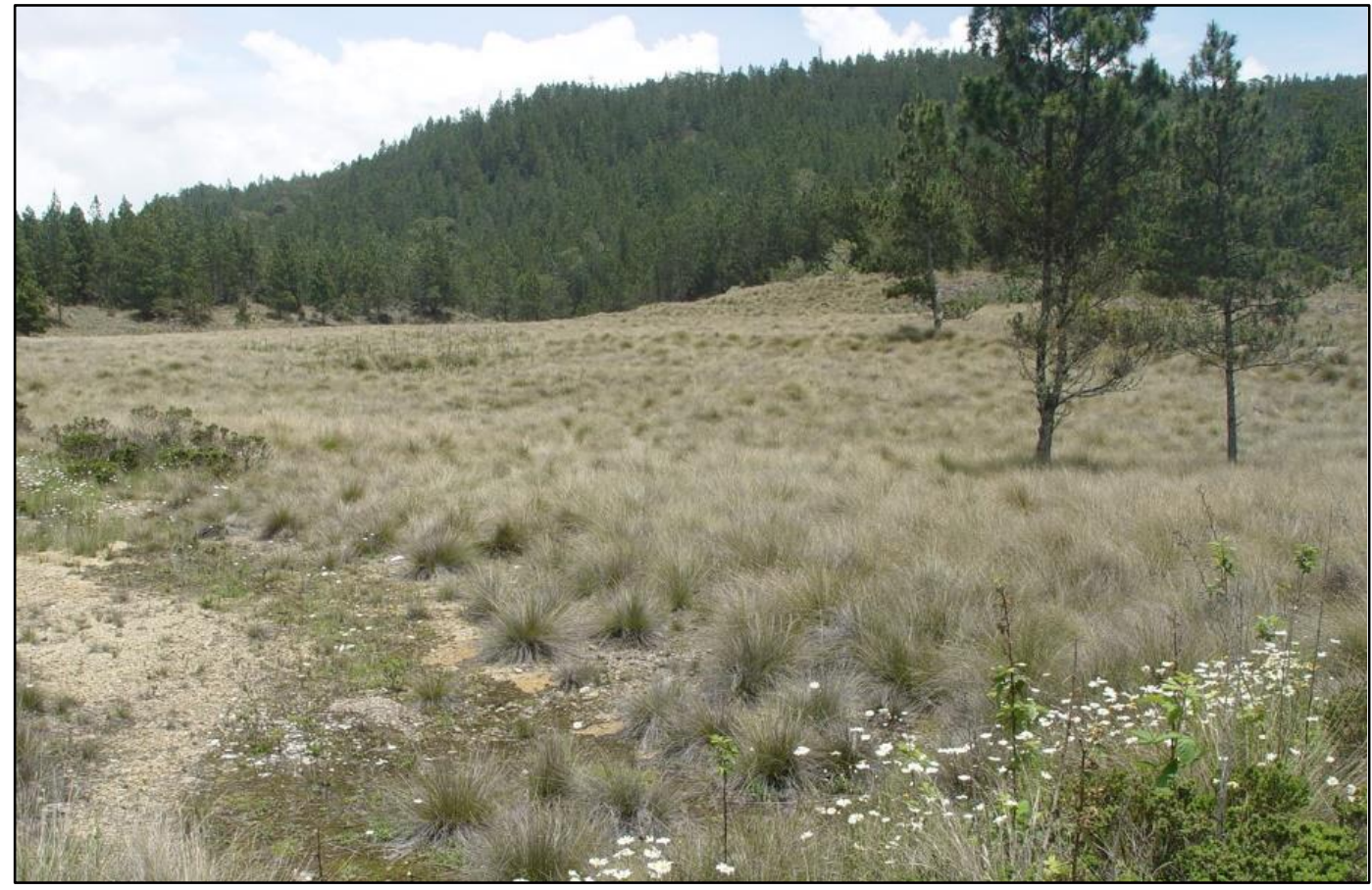

Figure 5. Hemicryptophytic communities of Danthonia domingensis Hack. \& Pilg. in the supratropical sector of Hispaniola (protected natural area of Valle Nuevo) located in the clearings of the Pinus occidentalis Sw. pine forests. La Pirámide, between Ocoa and Constanza. Dominican Republic (ph. E. Cano). 
Table 1. Diversity indices for the Caribbean (P1-P10) and Andean (P11-P15) plots. Pm: mean diversity (Simpson, Shannon and Margalef). In black the maximum values of diversity (P1 and P13), $\mathrm{Pm}=$ mean value of diversity.

\begin{tabular}{cccccccccccccccccc}
\hline & P1 & P2 & P3 & P4 & P5 & P6 & P7 & P8 & P9 & P10 & Pm & P11 & P12 & P13 & P14 & P15 & Pm \\
\hline $\begin{array}{c}\text { Species rich- } \\
\text { ness }\end{array}$ & 18 & 16 & 15 & 6 & 16 & 14 & 10 & 8 & 11 & 9 & 12.3 & 6 & 22 & 33 & 22 & 20 & 20.6 \\
Simpson_1-D & 0.94 & 0.94 & 0.93 & 0.83 & 0.94 & 0.93 & 0.9 & 0.88 & 0.91 & 0.89 & 0,91 & 0.83 & 0.95 & 0.97 & 0.95 & 0.95 & 0.93 \\
Shannon_H & 2.89 & 2.77 & 2.71 & 1.79 & 2.77 & 2.64 & 2.3 & 2.08 & 2.4 & 2.2 & 2.46 & 1.79 & 3.09 & 3.5 & 3.09 & 3 & 2.89 \\
Margalef & 5.88 & 5.41 & 5.17 & 2.79 & 5.41 & 4.93 & 3.9 & 3.37 & 4.17 & 3.64 & 4.47 & 2.79 & 6.79 & 9.15 & 6.79 & 6.34 & 6.37 \\
\hline
\end{tabular}

In our study we observe a clear difference between the Peruvian and Colombian grasslands and those of the Caribbean. Unfortunately, for the plots from Peru and Colombia we only have the reference by $[24,26]$ on the species of the genus Danthonia in the Colombian Andes, and the floristic composition of the Andean grasslands (Ecuador) is different from on the island of Hispaniola. Izco et al. [20] report that the southern scrublands of Ecuador comprise over 33 species, among which it is worth highlighting Agrostis tolucensis Kunth, Calamagrostis bogotensis Pilg., Calamagrostis intermedia Sted., Halenia wedeliana Gilg, Baccharis tricuneata Pers., Bejaria resinosa L.f. None of these species is found on the Caribbean islands. In their work on the vegetation of the central Andes in Peru, RivasMartínez \& Tovar [26] mention Calamagrostis vicunarum Pilg., which is not present in the Caribbean. Previously, the Caribbean scrublands have been located exclusively in the supratropical belt in Hispaniola, where they are dominated by Danthonia domingensis Hack \& Pilg. and Deschampsia domingensis Hichc. \& Ekman, accompanied by other hemicryptophytes and some woody shrubs. These are silicicolous communities that are interspersed with forests of Pinus occidentalis Sw. (Dendropemon phycnophylli-Pinetum occidentalis Cano, Velóz, \& Cano-Ortiz 2011) [51].

These hemicryptophyte communities located in the clearings of the pine forest are very rich in endemic plants, as they are located in the high mountains [67]. Although climate change affects the forest of $P$. occidentalis, it does not seem to affect these communities. With the death of the pine, open spaces appear that allow the expansion of the "pajón" or Danthonia domingensis, as occurs in the protected natural area of Valle Nuevo (Hispaniola), although globalization is leading to an increase in human pressure and jeopardising the conservation of these communities [39]. It is evident that if climate change and human pressure continue, these fragile communities that are unique to the Caribbean will come under a certain degree of threat, since a set of naturalised $(\mathrm{Na})$ species has already appeared as a result of anthropic action.

Cano et al. [50] recently published a syntaxonomical proposal for the grasslands of Hispaniola. This study reveals the existence of an endemic grassland community that is widespread throughout the supratropical thermotype in the central biogeographic sector, Central subprovince, Hispaniola province. This is an endemic community of grassland characterised by Alchemilla domingensis Urb., Hypericum constanzae Urb., Danthonia domingensis, Deschansia domingensis, Gautheria domingensis and Rubus eggersii which allows us to propose the association Hyperico constanzae-Danthonietum domingensis Cano, CanoOrtiz, Quinto Canas, Piñar Fuentes \& Pinto Gomes hoc loco (Table 2 relevé typus P1). The lack of phytosociological studies in which to include these communities leads us to propose higher ranking syntaxa, as follow:

DESCHAMPSIO-DANTHONIETEA DOMINGENSIS Cano, Cano-Ortiz, Quinto Canas, Piñar Fuentes \& Pinto Gomes class. nova

Caribbean supratropical grasslands [Danthonia domingensis, Deschampsia domingensis, Carex polystachya Se. ex Wahlenb, Baccharis myrsinites (Lam.) Pers., Panicum acuminatum Sw., Hieracium gronovii L., Gautheria domingensis Urb.]. 
DESCHAMPSIO-DANTHONIETALIA DOMINGENSIS Cano, Cano-Ortiz, Quinto Canas, Piñar Fuentes \& Pinto Gomes ord. novo

Caribbean supratropical grasslands [Danthonia domingensis, Deschampsia domingensis, Carex polystachya, Baccharis myrsinites, Panicum acuminatum, Hieraciun gronovii, Gautheria domingensis].

Hieracio domingensis-Deschampsion domingensis Cano, Cano-Ortiz, Quinto Canas, Piñar Fuentes \& Pinto Gomes all. nova

Endemic supratropical grasslands of Hispaniola [Rubus eggersii (Focker) Rydb., Deschampsia domingensis, Artemisia domingensis Urb., Chaptalia eggersii Urb.]

Although Chaptalia eggersii, does not appear in the sites sampled due to its dispersed presence in the pajonal community and its distribution, we also consider it to be characteristic of the alliance for which we propose as the holotype Hyperico constanzae-Danthonietum domingensis Cano, Cano-Ortiz, Quinto Canas, Piñar \& Pinto Gomes.

Hyperico constanzae-Danthonietum domingensis Cano, Cano-Ortiz, Quinto Canas, Piñar Fuentes \& Pinto Gomes ass. nova

Endemic grassland association, supratropical, located in the eastern zone of the central sector, Central subprovince, Hispaniola province, characterised by the endemisms: Alchemilla domingensis, Hypericum constanzae, Danthonia domingensis, Deschampsia domingensis (Table 2).

Table 2. Hyperico constanzae-Danthonietum domingensis ass. nova (Deschampsio-Danthonietea domingensis; Danthonietalia domingensis; Hieracio domingensis-Deschampsion domingensis). Localities: La Pirámide. Between Ocoa and Constanza. Dominican Republic. UTM: 19331098E/2069723N. Origin: $\mathrm{E}=$ Endemic, $\mathrm{N}=$ Native $\mathrm{Na}=$ Naturalised. Biotype: $\mathrm{H}=$ Hemicryptophyte, $\mathrm{Ar}=$ Shrub.

\begin{tabular}{lcccccccccccccl}
\hline Relevé no. & P1 & P2 & P3 & P4 & P5 & P6 & P7 & P8 & P9 & P10 & O & B & F & \\
Area $\left(\mathrm{m}^{2}\right)$ & 300 & 300 & 300 & 300 & 300 & 300 & 300 & 300 & 300 & 300 & R & I & A & \\
Cover $(\%)$ & 90 & 80 & 80 & 80 & 80 & 90 & 90 & 80 & 80 & 80 & I & O & M & \\
Altitude m a.s.l. $1=10$ & 238 & 235 & 228 & 230 & 210 & 220 & 226 & 230 & 235 & 218 & G & T & I & \\
Average vegetation height in metres & 0.45 & 0.45 & 0.50 & 0.50 & 0.40 & 0.55 & 0.50 & 0.55 & 0.60 & 0.55 & I & Y & L & \\
Slope & - & - & - & - & - & - & - & - & - & - & N & P & Y & \\
Exposition & - & - & - & - & - & - & - & - & - & - & & $E$ & & \\
\hline
\end{tabular}

\section{Characteristic species of association} and higher syntaxa

Danthonia domingensis

Hieracium domingensis

Deschampsia domingensis

Rubus eggersii

Hypericum diosmoides

Lyonia heptamera

Baccharis myrsinites

Satureja alpestris

Alchemilla domingensis

Rhynchospora domingensis

Hypericum constanzae

Hieracium gronovii

Gautheria domingensis

\begin{tabular}{|c|c|c|c|c|c|c|c|c|c|c|c|c|}
\hline 4 & 3 & 3 & 3 & 3 & 4 & 4 & 3 & 3 & 3 & E & $\mathrm{H}$ & Poaceae \\
\hline 1 & 2 & 2 & 1 & 1 & 2 & 1 & 1 & . & 1 & $\mathrm{E}$ & $\mathrm{H}$ & Asteraceae \\
\hline 1 & 1 & 1 & & 1 & 2 & . & . & 1 & . & E & $\mathrm{H}$ & Poaceae \\
\hline 1 & 1 & 1 & & 2 & 1 & . & . & 1 & . & $\mathrm{E}$ & $\mathrm{Ar}$ & Rosaceae \\
\hline+ & 1 & 1 & & 1 & . & . & . & . & . & $\mathrm{N}$ & $\mathrm{H}$ & Hypericaceae \\
\hline+ & + & . & ${ }^{\circ}$ & . & . & . & + & . & + & $\mathrm{E}$ & $\mathrm{Ar}$ & Ericaceae \\
\hline+ & 1 & 1 & . & . & 1 & . & . & . & . & $\mathrm{N}$ & $\mathrm{Ar}$ & Asteraceae \\
\hline+ & + & . & 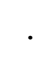 & + & + & . & . & . & . & $\mathrm{E}$ & $\mathrm{Ar}$ & Lamiaceae \\
\hline+ & + & . & & + & . & . & . & . & . & E & $\mathrm{H}$ & Rosacee \\
\hline . & + & . & & $\cdot$ & + & . & . & . & $\cdot$ & $\mathrm{N}$ & $\mathrm{H}$ & Cyperaceae \\
\hline 2 & 1 & . & & . & . & . & . & . & . & $\mathrm{E}$ & $\mathrm{H}$ & Hypericaceae \\
\hline 1 & 1 & . & & $\cdot$ & . & . & . & . & . & $\mathrm{N}$ & $\mathrm{H}$ & Asteraceae \\
\hline & 1 & & & & . & & . & . & & $E$ & $\mathrm{Ar}$ & Ericaceae \\
\hline
\end{tabular}


Malaxis unifolia

\section{Companion species}

Carex polystachya

Lycopodium fawcetii

Lycopodium cernua

Symphyotricum dumosum

Panicum acuminatum

Lycopodium clavatum

Centella asiatica

Pinus occidentalis

Sonchus oleraceus

Taraxacum officinale

Trifolium repens

Sisyrinchium angustifolium

Juncus effusus

Rumex cripus

Verbascum thapsus

Pteridium aquilinum

Verbena domingensis

Panicum acicularis

\begin{tabular}{|c|c|c|c|c|c|c|c|c|c|c|c|c|}
\hline+ & + & . & $\cdot$ & . & . & - & $\cdot$ & $\cdot$ & . & $\mathrm{N}$ & $\mathrm{H}$ & Orchidaceae \\
\hline 2 & 1 & . & + & 1 & . & . & + & 1 & + & $\mathrm{Na}$ & $\mathrm{H}$ & Cyperaceae \\
\hline 1 & 1 & . & 1 & . & 1 & . & 1 & . & + & $\mathrm{N}$ & $\mathrm{H}$ & Lycopodiaceae \\
\hline+ & . & + & . & . & + & + & + & . & + & $\mathrm{N}$ & $\mathrm{H}$ & Lycopodiaceae \\
\hline 1 & + & + & . & 1 & . & . & . & + & . & $\mathrm{Na}$ & $\mathrm{H}$ & Asteraceae \\
\hline . & + & + & . & + & + & . & . & + & . & $\mathrm{N}$ & $\mathrm{H}$ & Poaceae \\
\hline 2 & 1 & . & . & . & . & . & . & . & . & $\mathrm{Na}$ & $\mathrm{H}$ & Lycopodiaceae \\
\hline 1 & 1 & 1 & . & + & . & . & . & . & . & $\mathrm{Na}$ & $\mathrm{H}$ & Apiacee \\
\hline 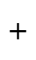 & . & . & + & . & + & + & . & . & + & $\mathrm{E}$ & Ar & Pinaceae \\
\hline & + & + . & . & . & . & + & + & + & + & $\mathrm{Na}$ & $\mathrm{H}$ & Asteraceae \\
\hline 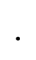 & + & + & . & + & + & + & . & . & . & $\mathrm{Na}$ & $\mathrm{H}$ & Asteraceae \\
\hline • & + & + & . & + & . & . & . & . & . & $\mathrm{Na}$ & $\mathrm{H}$ & Fabaceae \\
\hline$\cdot$ & + & . & . & . & . & . & . & . & . & $\mathrm{N}$ & $\mathrm{H}$ & Iridaceae \\
\hline • & + & . & . & + & . & . & . & + & . & $\mathrm{N}$ & $\mathrm{H}$ & Juncaceae \\
\hline$\cdot$ & + & + & . & + & + & + & . & + & . & $\mathrm{Na}$ & $\mathrm{H}$ & Polygonaceae \\
\hline+ & . & + & . & + & . & + & . & + & . & $\mathrm{Na}$ & $\mathrm{H}$ & Scrophulariaceae \\
\hline+ & . & . & + & & + & + & + & + & + & $\mathrm{N}$ & $\mathrm{H}$ & Hypolepidaceae \\
\hline . & . & . & . & . & . & + & . & . & . & $\mathrm{N}$ & $\mathrm{H}$ & Verbenaceae \\
\hline 1 & + & . & . & . & . & . & . & . & . & $\mathrm{Na}$ & $\mathrm{H}$ & Poaceae \\
\hline
\end{tabular}

\section{Conclusions}

The comparative analysis of Andean and Caribbean grasslands allows us to propose new syntaxa for the island of Hispaniola, as there are no phytosociological studies for these types of communities in the Caribbean. As these communities cannot be ascribed to any of the classes previously published for South America due to the major floristic and biogeographical differences between them, we propose a new class, order, alliance and association. These are endemic syntaxa that are currently restricted to the island of Hispaniola. Endemicity is due to the "insular effect": something similar occurs in other islands and peninsulas, including mountain areas, such as the Etna volcano on the island of Sicily (Italy), in which due to the above mentioned effect insular effect there are endemic taxa of interest [68]. The floristic diversity of the plots in the study reveals high values for Andean areas, with maximum Simpson, Shannon and Margalef values of 0.94, 2.89 and 5.88 (Hispaniola, Caribbean) and 0.97, 3.50 and 6.79 respectively (Andean areas). Altough this is also due to the intense anthropic activity on the island of Hispaniola, which has led to a high rate of naturalised plants - over $30 \%$-, endangering these habitats and consequently their endemisms, the high floristic diversity is determined above all by the high percentage of endemisms and native flora as a whole.

We highlight the importance of these plant communities in the Caribbean area, since they are unique phytocoenoses in this territory; so although there is little phytosociological information available, their very significant floristic divergences, the origin of the floras and the epiontological differences are sufficient reasons for the diagnosis of new syntaxa.

Consequently, the diagnosis of new syntaxa for science will allow the protection of these habitats.

Supplementary Materials: The following are available online at www.scipublications.com/journal/index.php/rjees/article/view/184/tabs1, Table S1: Species occurring in the sampling plots of the Caribbean and Ecuador. Localities of the plots. P1 and P2: La Pirámide (between 
Ocoa and Constanza), UTM:19331098E/2069723N. P3 to P10: Valle Nuevo, UTM: 19331998E/206923N [40]. P11 to P15 [14, 17]. X= Presence, - = Absence. Table S2: Comparative analysis of the flora in the plots $\mathrm{PE}=$ Island of Hispaniola. $\mathrm{PA}=$ Peruvian Andes..

\section{Author Contributions:}

Conceptualization, Eusebio Cano; Data curation, Ana Cano-Ortiz, Ricardo Quinto Canas, José Carlos Piñar Fuentes, Sara del Río, Carlos José Pinto Gomes and Eusebio Cano; Formal analysis, José Carlos Piñar Fuentes, Carlos José Pinto Gomes and Eusebio Cano; Funding acquisition, Ana Cano-Ortiz; Investigation, Ana Cano-Ortiz and Eusebio Cano; Methodology, Eusebio Cano; Resources, Eusebio Cano; Supervision, Eusebio Cano; Validation, Ana Cano-Ortiz, Ricardo Quinto Canas, José Carlos Piñar Fuentes and Eusebio Cano; Visualization, Ana Cano-Ortiz, and Eusebio Cano; Writing - original draft, Ana Cano-Ortiz and Eusebio Cano; Writing - review \& editing, Ana Cano-Ortiz, Ricardo Quinto Canas, José Carlos Piñar Fuentes, Sara del Río, Carlos José Pinto Gomes and Eusebio Cano.

Funding: Samplings were taken within the context of three projects by the AECI (Spanish International Cooperation Agency) from 2005 to 2007.

Acknowledgments: Ms Pru Brooke-Turner (M.A. Cantab.), a native English speaker specialized in scientific texts, has translated this article. The authors are very grateful to the two anonymous reviewers who helped improve the manuscript.

Conflicts of Interest: The authors declare no conflict of interest.

\section{References}

[1] Fang, J.Y. Exploring Altitudinal Patterns of Plant Diversity of China's Mountains. Biodivers. J. 2004, 12, 1-4.

[2] Al-Yemeni, M.; Sher, S. Biological Spectrum with More Other Ecological Attributes of the Flora and Vegetation of the Asir Mountain of SouthWest, Saudi Arabia. Afr. J. Biotech. 2010, 9, 5550-5559.

[3] Brullo, S.; Giusso del Galdo, G.; Guarino, R. The orophilous dwarf-shrub vegetation of Mt. Trodos (Cyprus). Bot. Chron. 2005, 18, 63-73.

[4] Frate, L.; Carranza, M.L.; Evangelista, A.; Stinca, A.; Schaminée, J.H.J.; Stanisci, A. Climate and land use change impacts on Mediterranean high-mountain vegetation in the Apennines since the 1950s. Plant Ecology E Diversity 2018, 11(1), 85-96, DOI: 10.1080/17550874.2018.1473521

[5] Meireles, C.; Pinto-Gomes, C.; Cano, E. Approach to climatophilous vegetation series of Serra da Estrela (Portugal). Acta Botanica Gallica 2012, 159(3), 283-287. DOI: 10.1080/12538078.2012.737147

[6] Pérez-García, F.J.; Medina-Cazorla, J.M.; Martínez-Hernández, F.; Garrido-Becerra, J.A.; Mendoza-Fernández, A.J.; Salmerón Sánchez, E.; Mota, J.F. The Baetic Endemic Flora: Taxonomic Structure, Ecological and Rarity Patterns. Implications for a Conservation Policy. Ann. Bot. Fenn. 2012, 49, 43-54.

[7] Tang, Z.Y.; Fang, J.Y. A Review on the Elevational Patterns of Plant Species Diversity. Biodivers. J. 2004, 12, 20-28.

[8] Singh, B.; Singh, B.; Borthakur, S.K.; Phukan, S.J. Contribution to Himalayan Hotspot: Assessment of Forest Types, Floristic Composition and Economic Wealth of Nokrek Biosphere Reserve in Northeast India. Indian Forest. 2018, 144, 734-741.

[9] Musarella, C.M.; Brullo, S.; Giusso del Galdo, G. Contribution to the Orophilous Cushion-Like Vegetation of Central-Southern and Insular Greece. Plants 2020, 9, 1678. https://doi.org/10.3390/plants9121678

[10] Brullo C, Brullo S, De Marco G, Giusso del Galdo G, Guarino R (2008) A survey of the orophilous shrubby vegetation of the Teide (Tenerife, Canary Islands). Feddes Rep 119(1-2):63-81

[11] Mollat, H.; Wagner, B.M.; Cepek, P.; Weiss, W. Mapa geológico de la República Dominicana 1:250.000. Geologisches Jahrbuch, ISBN, 3-510-95927-2, Hannover, 2004.

[12] ARN Atlas de los Recursos Naturales de la República Dominicana. Ed. Frank Moya Pons. Secretaria de Estado de Medio Ambiente y Recursos Naturales, Santo Domingo, 89 pp., 2004.

[13] Peguero, B. Diversidad y Estructura de la Vegetación en la Sabana de Pajón de Valle Nuevo, Cordillera Central, República Dominicana. Moscosoa 2013, 18, 137-153.

[14] Cano, E.; Cano Ortiz, A.; Del Río González, S.; Alatorre Cobos, J.; Veloz, A. Bioclimatic map of the Dominican Republic. Plant Soc. 2012, 49, 81-90. doi: 10.7338/pls2012491/04 
[15] Rivas Martínez, S.; Navarro, G.; Penas, A.; Costa, M. Biogeographic Map. of Sourh America. A preliminary survey. International Journal of Geobotanic Reserarch 2011, 1, 21-40.

[16] Izco, J. The Biological Reserve of San Francisco (Ecuador) revision of the syntaxonomy and nomenclature of the vegetation. Lazaroa 2013, 34, 257-266. DOI: 10.5209/rev-LAZA.2013.v34n1.43236.

[17] Cabrera, E.M.; Faggi, A.M.; Fontana, J.L.; Aceñolaza, P.; Gandullo, R.; Cabido, M.; Iriart, D.; Prado, D.; Roig, F.A.; Eskuche, U. Prodromus sistemático de la República Argentina. Bol. Soc. Argent. Bot. 2016, 51(3), 469-549.

[18] Galán de Mera, A.; Vicente Orellana, S.A. Aproximación al esquema sintaxonómico de la región del Caribe y América del Sur. Anales de Biología 2006, 28, 3-27.

[19] Arakaki, M.; Cano, A. Composición florística de la cuenca del río Ilo-Moquegua y lomas de Ilo, Moquegua, Perú. Rev. Peru. Biol. 2003, 10(1): 5-19.

[20] Izco, J.; Pulgar, I.; Aguirre, Z.; Santin, F. Estudio florístico de los páramos de pajonal meridional de Ecuador. Rev. Peru. Biol. 2007, 14(2), 237-146.

[21] Muñoz-Schick, M.; Moreira-Muñoz, A.; Moreira Espinosa, S. Origen del nombre de los géneros de plantas vasculares nativas de Chile y su representatividad en Chile y en el mundo. Gayana Bot. 2012, 69(2), 309-359.

[22] Biganzoli, F.; Zuloaga, F. Análisis de la diversidad de la familia Poaceae en la región austral de América del Sur. Rodriguésia 2015, 66(2): 337-351. DOI: 10.1590/2175-7860201566205.

[23] Rúgolo de Agrasar, Z.E.; García, N.; Mieres, G. Danthonia decumbens (Danthoniae, Poaceae), nueva especie adventicia para la flora de Chile continental. Gayana Bot. 2009, 66(1), 92-94.

[24] Giraldo-Cañas, D. Las gramíneas en Colombia. Riqueza, distribución, endemismo, invasión, migración, usos y taxonomías populares. Universidad Nacional de Colombia 383 pp., 2013.

[25] Pulgar, I.; Izco, J.; Jadán, O. Flora selecta de los pajonales de Loja (Ecuador). Ediciones Abya-Yala. 171 pp., 2010.

[26] Rivas Martínez, S.; Tovar, O. Vegetatio Andinae, I. Datos sobre las comunidades vegetales altoandinas de los Andes Centrales de Perú. Lazaroa 1982, 4, 167-187.

[27] Ibisch, P.L. Flora y vegetación de la provincia Arque. Departamento Cochobamba, Boliva. Ecología en Bolivia 1994, $22,43-52$.

[28] García, R.; Mejía, M.; Zanoni, T. Composición florística y principales asociaciones vegetales en la Reserva Científica de Evano Verde, Cordillera Central, República Dominicana. Moscosoa 1994, 8, 86-130.

[29] García, R.; Mejía, M.; Peguero, B.; Jiménez, F. Flora endémica de la sierra de Bahoruco, República Dominicana. Moscosoa 2001, $12,9-44$.

[30] Guerrero, A.; Jiménez, F.; Höner, D.; Zanoni, T. La flora y la vegetación de la loma Barbacoa, Cordillera Central, República Dominicana. Moscosoa 1997, 9, 84-116.

[31] Cano Ortiz, A.; Musarella, C.M.; Pinto Gomes, C.J.; Quinto Canas, R.; Piñar Fuentes, J.C.; Cano, E. Phytosociological Study, Diversity and Conservation Status of the Cloud Forest in the Dominican Republic. Plants 2020, 9 , 741. https://doi.org/10.3390/plants9060741

[32] Cano, E.; Cano-Ortiz, A.; Del Río, S.; Veloz, A.; Esteban Ruiz, F.J. A phytosociological survey of some serpentine plant communities in the Dominican Republic. Plant Biosyst 2013, 148(2), 200-212. http://dx.doi.org/10.1080/11263504.2012.760498.

[33] Cano-Ortiz, A.; Musarella, C.M.; Piñar, J.C.; Veloz, A.; Cano, E. Vegetation of the dry bioclimatic areas in the Dominican Republic. Plant Biosyst 2015, 149(3), 451-472. https://doi.org/10.1080/11263504.2015.1040482

[34] Cano-Ortiz, A.; Musarella, C.M.; Piñar Fuentes, J.C.; Pinto Gomes, C.J.; Cano, E. Distribution patterns of endemic flora to define hotspots on Hispaniola. Syst and Biodiv 2016, 14(3), 261-271. https://doi.org/10.1080/14772000.2015.1135195.

[35] Höner, D.; Jiménez, F. Flora vascular y vegetación de la loma la Herradura (Cordillera Oriental), República Dominicana. Moscosoa 1994, 8, 65-85.

[36] Githiru, M.; Njambuya, J.W. Globalization and Biodiversity Conservation Problems: Polycentric REDD+ Solutions. Land 2019, $8,35$.

[37] May, T. Tres años de obervaciones fenológicas en el bosque nublado de Casabito (Reserva científica Ebano Verde, Cordillera Central, República Dominicana). Moscosoa 1998, 10, 164-178.

[38] May, T. Respuesta de la vegeteción en un calimetal de Dicranopteris pectinata después de un fuego, en la parte oriental de la Cordillera Central, República Dominicana. Moscosoa 2000, 11, 113-132.

[39] May, T. Composition, structure and diversity in broadleaved cloud forests in the Ebano Verde scientific reserve (Cordillera Central range, Dominican Republic). Moscosoa 2007, 15, 156-176.

[40] May, T.; Peguero, B. Vegetación y flora de la loma el Mogote, Jarabacoa, Cordillera Central, República Dominicana. Moscosoa 2000, 11, 11-37. 
[41] Mejía, M.; García, R.; Jiménez, F. Sub-región fitogeográfica Barbacoa-Casabito: riqueza florística y su importancia en la conservación de la flora de la isla Española. Moscosoa 2000, 11, 57-106.

[42] Mejía, M.; Jiménez, F. Flora y vegetación de la loma la Humeadora, Cordillera Central, República Dominicana. Moscosoa 1998, $10,10-46$.

[43] Mejía, M.; Pimentel, J.; García, R. Árboles y Arbustos de la región Cársica de los Haitises, República Dominicana. Moscosoa 2011, $17,90-114$.

[44] Hager, J.; Zanoni, T. La vegetación natural de la República Dominicana: Una nueva clasificación. Moscosoa 1993, 7, 39-81.

[45] Veloz, A. Flora y vegetación del Monte Jota, Sierra de Bahoruco, Provincia Independencia, República Dominicana. Moscosoa 2007, 15: 206-217.

[46] Zanoni, T. La flora y la vegetación de loma Diego de Ocampo, Cordillera Septentrional, República Dominicana. Moscosoa 1990, 6, 19-45.

[47] Zanoni, T.; Mejía, M.; Pimentel, J.D.; García, R.G. La flora y vegetación de los Haitises, República Dominicana. Moscosoa 1990, 6, 46-97.

[48] Cano, E.; Veloz Ramirez, A.; Cano Ortiz, A. Phytosociological study of the Pinus occidentalis forests in the Dominican Republic. Plant Biosyst. 2011, 145, 286-297. https://doi.org/10.1080/11263504.2010.547685

[49] Cano, E.; Cano Ortiz, A.; Del Río, S.; Veloz, A.; Esteban, FJ. A phytosociological survey of some serpentine plant communities in the Dominican Republic. Plant Biosyst. 2014, 148 (2), 200-212. https://doi.org/10.1080/11263504.2012.760498

[50] Cano Ortiz, A.; Musarella, C.M.; Piñar Fuentes, J.C.; Bartolomé Esteban, C.; Quinto-Canas, R.; Pinto Gomes, C.J.; Del Río González, S.; Cano, E. (2018). Advances in the Knowledge of the Vegetation of Hispaniola (Caribbean Central America). In Vegetation; Sebata, A., ed.; InthechOpen: London, UK, pp. 83-99. DOI: 10.5772/intechopen.72090

[51] Cano, E.; Velóz Ramirez, A.; Cano-Ortiz, A.; Esteban, F.J. Distribution of Central American Malastomataceae: Biogeographical Analysis of the Caribbean Islands. Acta Bot. Gallica 2009, 156(4), 527-557. https://doi.org/10.1080/12538078.2009.10516176

[52] Perrino, E.V.; Tomaselli, V.; Costa, R.; Pavone, P. Conservation status of habitats (Directive 92/43 EEC) of coastal and low hill belts in a mediterranean biodiversity hot spot (Gargano - Italy). Plant Biosystems 2013, 147(4), 1006-1028. https://doi.org/10.1080/11263504.2013.860052

[53] Muzafar, I.; Khuroo, A.A.; Mehraj, G.; Hamid, M.; Rashid, I.; Malik, A.H. Floristic diversity along the roadsides of an urban biodiversity hotspot in Indian Himalayas. Plant Biosyst. 2019, 153, 222-230. https://doi.org/10.1080/11263504.2018.1461700

[54] Singh, S.; Singh, B.; Surmal, O.; Bhat, M.N.; Singh, B.; Musarella, C.M. Fragmented Forest Patches in the Indian Himalayas Preserve Unique Components of Biodiversity: Investigation of the Floristic Composition and Phytoclimate of the Unexplored Bani Valley. Sustainability 2021, 13, 6063. https://doi.org/10.3390/su13116063

[55] Mendoza-Fernández, A.J.; García, F.J.P.; Martínez-Hernández, F.; Salmerón-Sánchez, E.; Medina-Cazorla, J.M.; Garrido-Becerra, J.A.; Martínez-Nieto, M.I.; Calvente, M.E.M.; Mota, J.F. Areas of endemism and threatened flora in a Mediterranean hotspot: Southern Spain. J. Nat. Conserv. 2015, 23, 35-44. https://doi.org/10.1016/j.jnc.2014.08.001

[56] Cano Ortiz, A.; Piñar Funetes, J.C.; Ighbareyeh, J.M.H.; Quinto Canas, R.; Cano, E. Aspectos Didácticos en la Enseñanza de Conceptos Geobotánicos. International Journal of Humanities Social Sciences and Education (IJHSSE) 2021, vol 8, $\mathrm{n}^{\mathrm{a}}$ 4, 271-276, https://doi.org/10.20431/2349-0381.0804022.

[57] Braun-Blanquet, J. Fitosociología: Bases Para el Estudio de las Comunidades Vegetales; Blume: Madrid, Spain, 1979.

[58] Theurillat, J. P.; Willner, W.; Fernández-González, F.; Bültmann, H.; Čarni, A.; Gigante, D.; Mucina, L. \& Weber, H. (2020). International Code of Phytosociological Nomenclature. 4th edition. Applied Vegetation Science, 2020, 1-169. https://doi.org/10.1111/avsc.12491.

[59] Hammer, Ø.; Harper, D.A.T.; Paul, D.R. Past: Paleontological statistics software package for education and data analysis. Palaeontol. Electron. 2001, 4, 1-9.

[60] Rivas Martínez, S.; Tovar, O. Síntesis biogeográfica de los Andes. Collectanea Botanica 1983, 14, 515-521.

[61] Rivas-Martínez, S.; Sánchez Mata, D.; Costa, M. North American boreal and western temperate forest vegetation. Syntaxonomical synopsis ot the potential natural plant communities of North America, II. Itinera Geobot. 1999, 12, 5-326.

[62] Cano, E.; Veloz Ramirez, A.; Cano Ortiz, A. Contribution to the biogeography of the Hispaniola (Dominican Republic, Haiti). Acta Bot. Gall. 2010, 157, 581-598. https://doi.org/10.1080/12538078.2010.10516233

[63] Cano, E.; Musarella, CM.; Cano Ortiz, A.; Quinto Canas, R.; Piñar Fuentes, J.C.; Pinto Gomes, C.J.; Spampinato, G. High mountain vegetation of the Antilles (Caribbean). XIIe Séminaire Internacional Gestion et Conservation de la Biodiversité: Plantes. Végétations et paysages de montagne. Centre d'étude et de conservation des ressources végétales. Ordino (Principauté d'Andorre). Botanique 2018, 4 Supplément 1: 12-15. Juillet 10-17. 
[64] Cano Ortiz, A.; Musarella, C.M.; Cano, E. (2017). Biogeographical Areas of Hispaniola (Dominican Republic, Republic of Haiti) in Plant Ecology. INTECH PLUBISHER. University Campus, Croatia, pp. 165-189. DOI: 10.5772/intechopen.69081

[65] GBIF - Global Biodiversity Information Facility. Available online: https://www.gbif.org (accessed on 13 December 2020).

[66] Liogier, A.H.; La Flora de la Española. Jardín Botánico Nacional Dr. Rafael Ma. Moscoso, Santo Domingo, I-IX, $1996-2000$.

[67] Fakhry, A.M.; El-Keblawy, A.; Shabana, H.A.; Gamal, I.E.; Shalouf, A. Microhabitats Affect Population Size and Plant Vigor of Three Critically Endangered Endemic Plants in Southern Sinai Mountains, Egypt. Land 2019, 8, 86.

[68] Sciandrello, S.; Minissale, P.; Giusso del Galdo, G. Vascular plant species diversity of Mt. Etna (Sicily): endemicity, insularity and spatial patterns along the altitudinal gradient of the highest active volcano in Europe. PeerJ 2020, 8:e9875 https://doi.org/10.7717/peerj. 9875 


\title{
Endemic Hemicryptophyte Grasslands of the High Mountains of the Caribbean
}

\author{
Ana Cano-Ortiz ${ }^{1}$, Ricardo Quinto Canas ${ }^{2,3}$, José Carlos Piñar Fuentes ${ }^{1}$, Sara del Río ${ }^{4}$, Carlos José Pinto Gomes ${ }^{5}$ \\ and Eusebio Cano ${ }^{1, *}$
}

SUPPLEMENTARY MATERIAL

Table S1. Species occurring in the sampling plots of the Caribbean and Ecuador. Localities of the plots. P1 and P2: La Pirámide (between Ocoa and Constanza), UTM:19331098E/2069723N. P3 to P10: Valle Nuevo, UTM: 19331998E/206923N [40]. P11 to P15 $[14,17]$. $X=$ Presence, $-=$ Absence.

\begin{tabular}{|c|c|c|c|c|c|c|c|c|c|c|c|c|c|c|c|}
\hline & P1 & $\mathbf{P 2}$ & P3 & $\mathbf{P 4}$ & P5 & P6 & P7 & P8 & P9 & P10 & P11 & P12 & P13 & P14 & P15 \\
\hline Danthonia domingensis & $x$ & $x$ & $x$ & $x$ & $X$ & $X$ & $x$ & $x$ & $x$ & $x$ & - & - & - & - & - \\
\hline Carex polystachya & $x$ & $x$ & - & $X$ & $X$ & - & - & $x$ & $x$ & $x$ & - & - & - & - & - \\
\hline Hieracium domingensis & $x$ & $x$ & $X$ & $x$ & $X$ & $X$ & $x$ & $x$ & - & $x$ & - & - & - & - & - \\
\hline Lycopodium fawcetii & $x$ & $x$ & - & $x$ & - & $X$ & - & $x$ & - & $x$ & - & - & - & - & - \\
\hline Deschansia domingensis & $x$ & $x$ & $X$ & - & $X$ & $X$ & - & - & $x$ & - & - & - & - & - & - \\
\hline Rubus eggersii & $x$ & $x$ & $x$ & - & $X$ & $x$ & - & - & $x$ & - & - & - & - & - & - \\
\hline Sonchus oleraceus & - & - & $x$ & - & - & - & $x$ & $x$ & $x$ & $x$ & - & - & - & - & - \\
\hline Lycopodium cernua & - & - & $x$ & - & - & $x$ & $x$ & $x$ & - & $x$ & - & - & - & - & - \\
\hline Pteridium aquilinum & - & - & - & $X$ & - & $x$ & $x$ & $x$ & $x$ & $x$ & - & - & - & - & - \\
\hline Pinus occidentalis & $x$ & - & - & $x$ & - & $x$ & $x$ & - & - & $x$ & - & - & - & - & - \\
\hline Panicum acuminatum & - & - & $x$ & - & $X$ & $x$ & - & - & $x$ & - & - & - & - & - & - \\
\hline Rumex cripus & - & - & $x$ & - & $X$ & $x$ & $x$ & - & $x$ & - & - & - & - & - & - \\
\hline Verbascum thapsus & - & - & $x$ & - & $x$ & - & $x$ & - & $x$ & - & - & - & - & - & - \\
\hline Baccharis myrsinites & $x$ & $x$ & $x$ & - & - & $x$ & - & - & - & - & - & - & - & - & - \\
\hline Hypericum diosmoides & $x$ & $x$ & $x$ & - & $X$ & - & - & - & - & - & - & - & - & - & - \\
\hline Centella asiatica & $x$ & $x$ & $x$ & - & $x$ & - & - & - & - & - & - & - & - & - & - \\
\hline Taraxacum officinale & - & - & $x$ & - & $x$ & $x$ & $x$ & - & - & - & - & - & - & - & - \\
\hline Siryrinchium angustifolium & - & - & $X$ & - & $X$ & - & - & - & $x$ & - & - & - & - & - & - \\
\hline Lyonia heptamera & - & - & - & - & - & - & - & $x$ & - & $x$ & - & - & - & - & - \\
\hline Juncus effusus & - & - & - & - & $X$ & - & - & - & $x$ & - & - & - & - & - & - \\
\hline Alchemilla domingensis & $x$ & - & - & - & $x$ & - & - & - & - & - & - & - & - & - & - \\
\hline Hypericum constanzae & $x$ & $x$ & - & - & - & - & - & - & - & - & - & - & - & - & - \\
\hline Symphyotricum dumosum & $x$ & $x$ & - & - & - & - & - & - & - & - & - & - & - & - & - \\
\hline Panicum acicularis & $x$ & $x$ & - & - & - & - & - & - & - & - & - & - & - & - & - \\
\hline Hieracium gronovii & $x$ & $x$ & - & - & - & - & - & - & - & - & - & - & - & - & - \\
\hline Lycopodium clavatum & $x$ & $x$ & - & - & - & - & - & - & - & - & - & - & - & - & - \\
\hline Gaultheria domingensis & $x$ & $x$ & - & - & - & - & - & - & - & - & - & - & - & - & - \\
\hline Malaxis unifolia & $x$ & $x$ & - & - & - & - & - & - & - & - & - & - & - & - & - \\
\hline Trifolium repens & - & - & $X$ & - & $x$ & - & - & - & - & - & - & - & - & - & - \\
\hline
\end{tabular}


Satureja alperstris

Rhynchospora domingensis Verbena domingensis

Baccharis tricuneata

Elleanthus amethystinoides

Nertera granadensis

Oreobolus venezuelensis

Panicum stigmosum

Setaria parviflora

Bejaria resinosa

Cicendia quadrangularis

Danthonia secundiflora

Diplostephium hartwegii

Eriosorus cheilanthoides

Gaultheria erecta

Halenia taruga-gassso

Hieracium soridoanum

Histiopteris incisa

Huperzia afinis

Huperzia austroecuadorica Ilex rupicola

Lachemilla holosericea

Miconia aspergillaris

Miconia bullata

Myrcianthes myrsinoides

Thelypteris pusilla

Themistoclesia epiphytica

Triniochloa stipoides

Vaccinium crenatum

Viola arguta

Agrostis tolucensis

Bidens andicola

Briza monandra

Calamagrostis bootensis

Calamagrostis intermedia

Castilleja fissifolia

Diplostephium glandulosum

Eryngium humile

Geranium diffusum

Gomphichis caucana

Halenia weddeliana

Hieracium frigidum

Huperzia sellifolia

Hypochaeris sessiliflora

Isidrogalvia falcata

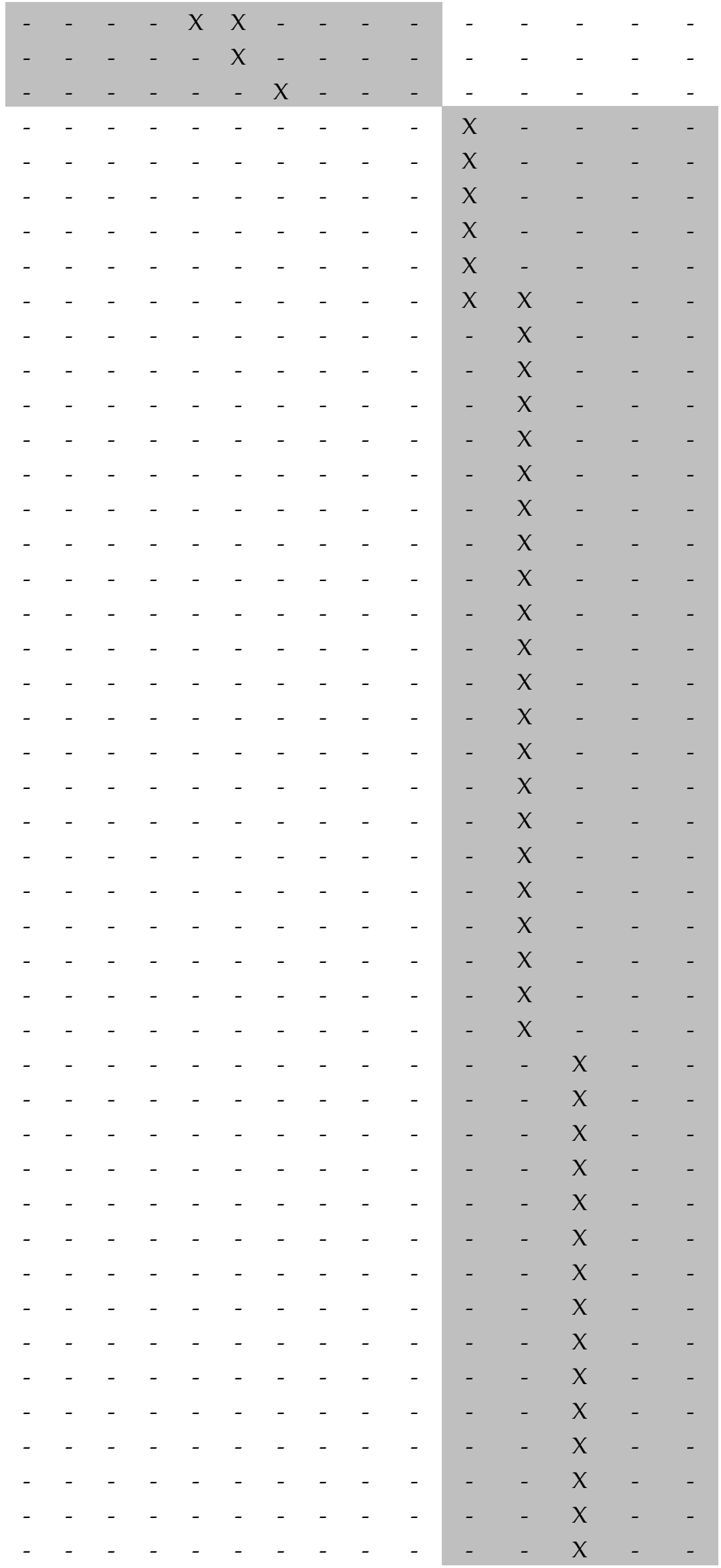


Lupinus tauris

Lycopodiella alopecuroides

Oreobolus goeppingeri

Oritrophium mucidum

Oriotrophium peruvianum

Pascpalum bomplandianum

Pedicularis incurva

Pinguicula calyptrata

Poa pauciflora

Puya glomerifera

Rhynchospora tenuis

Rhynchospora vulcani

Scirpus rigidus

Sisyrinchium chilense

Sisyrinchim tinctorium

Sticherus revolutus

Vaccinium floribundum

Valeriana microphylla

Brachyotum benthamianum

Gerarinum loxense

Gynoxys cuicochensis

Jamesonia gaudotii

Oritrophium crocifolium

Pentacalia andicola

Werneria nubigena

Baccharis teindalensis

Blechnum loxense

Blechnum schomburgkii

Eriocaulon microcephalum

Festuca glumosa

Festuca sabulifolia

Gaultheria reticulata

Hydrocotyle umbellata

Hypericum harlingii

Huperzia attenuata

Miconia asperrima

Monnina crassifolia

Niphlogeton dissecta

Ranunculus peruvianus

Calamagrostis ligulata

Calamagrostis ecuadorensis

Cortaderia hapalotricha

Cortaderia sericantha

Diplostephium oblanceolatum

Disterigma empetrifolium 
Gentianella fascicaulis

Huperzia crassa

Hydrocotyle ranunculoides

Hypericum lancioides

Lysipomia cuspidata

Lysipomia cylindrocarpa

Neurolepis aristata

Neurolepis nana

\begin{tabular}{lllllllllllllll}
- & - & - & - & - & - & - & - & - & - & - & - & - & - & $X$ \\
- & - & - & - & - & - & - & - & - & - & - & - & - & - & $X$ \\
- & - & - & - & - & - & - & - & - & - & - & - & - & - & $X$ \\
- & - & - & - & - & - & - & - & - & - & - & - & - & - & $X$ \\
- & - & - & - & - & - & - & - & - & - & - & - & - & - & $X$ \\
- & - & - & - & - & - & - & - & - & - & - & - & - & - & $X$ \\
- & - & - & - & - & - & - & - & - & - & - & - & - & - & $X$ \\
- & - & - & - & - & - & - & - & - & - & - & - & - & - & $X$ \\
\hline
\end{tabular}

Table S2 - Comparative analysis of the flora in the plots PE = Island of Hispaniola. PA = Peruvian Andes.

\section{Danthonia domingensis}

Hieracium domingensis

Carex polystachya

Deschansia domingensis

Rubus eggersii

Sonchus oleraceus

Lycopodium fawcetii

Pteridium aquilinum

Hypericum diosmoides

Baccharis myrsinites

Centella asiatica

Pinus occidentalis

Panicum acuminatum

Rumex cripus

Verbascum thapsus

Taraxacum officinale

Lycopodium cernua

Hypericum constanzae

Symphyotricum dumosum

Panicum acicularis

Hieracium gronovii

Lycopodium clavatum

Gaultheria domingensis

Malaxis unifolia

Rhynchospora domingensis

Lyonia heptamera

Trifolium repens

Siryrinchium angustifolium

Juncus effusus

Satureja alperstris

\begin{tabular}{lll} 
PE & PA \\
V & - \\
V & - \\
IV & - \\
III & - \\
III & - \\
III & - \\
III & - \\
III & - \\
II & - \\
II & - \\
II & - \\
II & - \\
II & - \\
II & - \\
II & - \\
II & - \\
II & - \\
I & - \\
I & - \\
I & - \\
I & - \\
I & - \\
I & - \\
I & - \\
I & - \\
I & - \\
\hline
\end{tabular}


Alchemilla domingensis

Verbena domingensis

Oritrophium crocifolium

Pentacalia andicola

- $\quad$ II

Setaria parviflora

- $\quad$ II

Brachyotum benthamianum

- II

Gerarinum loxense

- II

Gynoxys cuicochensis

- $\quad$ II

Jamesonia gaudotii

- $\quad$ II

Werneria nubigena

- II

Baccharis tricuneata

- I

Bejaria resinosa

Cicendia quadrangularis

Danthonia secundiflora

Diplostephium hartwegii

Elleanthus amethystinoides

Eriosorus cheilanthoides

Gaultheria erecta

- I

- I

- I

- I

- I

- I

- I

Halenia taruga-gassso

- I

Hieracium soridoanum

- I

Histiopteris incisa

- I

Huperzia afinis

- I

Huperzia austroecuadorica

Ilex rupicola

- I

Lachemilla holosericea

Miconia aspergillaris

- I

- I

Miconia bullata

Myrcianthes myrsinoides

- I

- I

Nertera granadensis

Oreobolus venezuelensis

Panicum stigmosum

Thelypteris pusilla

Themistoclesia epiphytica

Triniochloa stipoides

- I

- I

- I

- I

- I

- I

Vaccinium crenatum

- I

Viola arguta

Agrostis tolucensis

Bidens andicola

- I

- I

- I

Briza monandra

Calamagrostis bootensis

Calamagrostis intermedia

- I

- I

- I 
Castilleja fissifolia

- I

Diplostephium glandulosum

- I

Eryngium humile

- I

Geranium diffusum

Gomphichis caucana

- I

- I

Halenia weddeliana

- I

Hieracium frigidum

- I

Huperzia sellifolia

Hypochaeris sessiliflora

- I

- I

Isidrogalvia falcata

Lupinus tauris

- I

- I

Lycopodiella alopecuroides

- I

Oreobolus goeppingeri

Oritrophium mucidum

Oriotrophium peruvianum

Pascpalum bomplandianum

Pedicularis incurva

Pinguicula calyptrata

Poa pauciflora

Puya glomerifera

Rhynchospora tenuis

Rhynchospora vulcani

Scirpus rigidus

Sisyrinchium chilense

Sisyrinchim tinctorium

Sticherus revolutus

- I

- I

- I

- I

- I

- I

- I

- I

- I

- I

- I

- I

- I

- I

- I

- I

Valeriana microphylla

Baccharis teindalensis

Blechnum loxense

- I

- I

Blechnum schomburgkii

Calamagrostis ecuadorensis

Calamagrostis ligulata

Cortaderia hapalotricha

Cortaderia sericantha

Diplostephium oblanceolatum

- I

- I

- I

- I

- I

- I

Disterigma empetrifolium

- I

Eriocaulon microcephalum

- I

Festuca glumosa

- I

Festuca sabulifolia

- I

Gaultheria reticulata 
Gentianella fascicaulis

- I

Huperzia attenuata

- I

Huperzia crassa

- I

Hydrocotyle ranunculoides

- I

Hydrocotyle umbellata

- I

Hypericum harlingii

- I

Hypericum lancioides

- I

Lysipomia cuspidata

- I

Lysipomia cylindrocarpa

- I

Miconia asperrima

- I

Monnina crassifolia

- I

Neurolepis aristata

- I

Neurolepis nana

- I

Niphlogeton dissecta

- I

Ranunculus peruvianus 